ISSN 0258-7122

Bangladesh J. Agril. Res. 38(1): 105-114, March 2013

\title{
ESTIMATION OF GENETIC DIVERGENCE IN LABLAB BEAN (Lablab purpureus L.) GENOTYPES
}

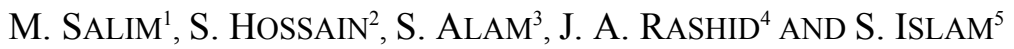

\begin{abstract}
An experiment for diversity analysis with 66 genotypes of lablab bean (Lablab purpureus L.) was conducted at Department of Genetics and Plant Breeding, Bangladesh Agricultural University (BAU) during 2009-2010. Data were collected from all experimental plants on the following characters: days to first flowering, days to $50 \%$ flowering, days to first pod setting, no. of pods per plant, wt. of 20 pods (g), pod yield per plant $(\mathrm{g})$, pod length $(\mathrm{cm})$, number of seeds per pod, number of seeds per plant, 100-seed weight (g), and seed yield per plant (g). As per multivariate analysis, the genotypes were grouped into seven clusters. The highest number of genotypes 15 was included in cluster $\mathrm{V}$ followed by cluster II, which contained 13 genotypes. Cluster III, I, VI, IV contained 12, 11, 6, and 5 genotypes, respectively. The cluster VII which included 4 genotypes was the smallest among the 7 clusters. It is important to note that the highest amount of genetic divergence within the cluster group was noticed in the cluster VII having only 4 genotypes. The inter-cluster distances $\left(\mathrm{D}^{2}\right)$ were higher than the intra-cluster distances. The inter-cluster $\mathrm{D}^{2}$ values varied from 2059.094 to 19302.6. The distances between the cluster VII and V; VII and VI; VII and II and VII and I were comparatively high than the other inter-cluster distances. The genotypes of these clusters were thus more diversified for yield and yield contributing characters. The intracluster distance (8502.795) observed in cluster VII revealed maximum diversity among themselves. While the least variation (625.372) was noticed between genotypes of the cluster II signifying the closeness of the genotypes included in this cluster. Data on the contribution of individual characters towards divergence suggested that no. of pods per plant contributed maximum $(34.033 \%)$ to the genetic divergence followed by pod yield per plant and 100-seed weight. The genotypes of the cluster VII produced highest pods per plant and those of the cluster II produced lowest pod yield per plant. Seed yield per plant was found to be highest in cluster VII and lowest in cluster II. Results of the study suggested that selection for these traits in climbing genotypes might be effective. By strategically using this diversity, the breeder can develop high yielding varieties of lablab bean.
\end{abstract}

Keyword: lablab bean, genetic parameter, genetic divergence, cluster, cluster mean, percent divergence.

\footnotetext{
${ }^{1}$ Scientific Officer, ${ }^{2}$ Scientific Officer, Hill Agricultural Research Station, BARI, Khagrachari, ${ }^{3}$ Scientific Officer, Regional Agricultural Research Station, Akbarpur Moulivi Bazar, ${ }^{4}$ Research and Development Officer, MATEX, Foundation, Gazipur, ${ }^{5}$ M.S Student, Dept. of Agronomy Bangladesh Agricultural University, Mymensingh.
} 


\section{Introduction}

All beans are a rich source of plant protein, calories, various vitamins, and minerals to diets based on cereal and/or starchy foods. There are many species of beans representing as many as eight or more genera. They are suited to grow in diverse geographical and agro-ecological conditions throughout the world. Lablab bean (Lablab purpureus L.) commonly known as country bean or deshi sheem in Bangladesh is a highly proteineous legume and a major winter vegetable.

Lablab bean can be grown in a wide range of soil with average fertility as for other beans (Nath, 1976). It is a perennial crop with twinning, creeping or bushy habit. Generally it is cultivated as annual or biennial crop. Its cultivation and use are so widespread that in the winter, it would be almost impossible to find a homestead in rural Bangladesh without a vine of country bean. This bean is considered as one of the oldest cultivated crops of the world (Bullivant, 1963). It is believed to have originated in India Subcontinent (Nath, 1976; Purseglove,1977; Yamaguchi, 1983; Chakravarty, 1986; Katyal and Chandha, 1988 and Chowdhury et al., 1989). Among the lablab bean growing countries, Bangladesh, India, Malaysia, Indonesia, Philippines, Papua New Guinea, China, Japan, Australia, North Africa, South and East Africa, the Carribbean, South and Central America are most noteworthy (Bailey, 1942; Rashid, 1976 and Tindall, 1988). In Bangladesh, Chittagong and coastal regions are especially reputed for its cultivation (CFLIP, 1988).

There is a big gap between the need and supply of vegetables in Bangladesh. The production of bean in our country was 83 thousand metric tons during 20062007. Though vegetable production is increasing day by day it fails keeping pace with ever increasing population and the demand. In Bangladesh, the vegetable production in kharif (summer) season is very low. During the months of April to May and August to October, which are regarded as 'lean periods' for vegetable, there is an acute scarcity with corresponding price hike. So photoperiod-neutral lablab beans, which, if possible to grow during these lean periods, will be a good proposition. Lablab bean plays an important role in the agro-ecosystem, national health and nutrition of Bangladesh. The average yield of lablab bean in Bangladesh is very low ( $4.8 \mathrm{t} / \mathrm{ha})$ as compared to in global context (10 t/ha.). This low yield status is attributed to the lack of prescribed production practices and lack of high potential varieties. Most of the varieties grown in Bangladesh are photoperiod sensitive and timely fixed with indeterminate growth habit. They only flower and produce edible pods during winter season under short day length. Apart from consuming as vegetable or pulse in Asia, Lablab purpureus is widely grown as a forage or green manure crop in the tropics and subtropics (Wood, 1983; Purseglove, 1977). Edible pods of lablab bean provide substantial amount of protein in addition to vitamin A, vitamin C, riboflavin, and potassium, iron, 
sulfur and sodium (Deka and Sarker, 1990; Newaz, 1992). The yield per plant or per unit area of lablab bean varies greatly, which is due to many genetical, physiological and environmental causes and such constraints require to be overcome by developing suitable genotypes. Genotypes having better perse performance under clusters I, II, V, VI, and VII could be selected for variety improvement program in lablab bean.

\section{Materials and Method}

The experimental plot was located at the Genetics and Plant Breeding Experimental Farm, Bangladesh Agricultural University (BAU), Mymensingh, and the experimental period was from August 2009 to April 2010. Sixty-six climbing genotypes were used in the experiment. The seeds of these genotypes were obtained from the Lablab Bean Research Programme of Genetics and Plant Breeding Department, BAU. The Experimental materials (genotypes) included a number of advanced generation lines along with parental genotypes and land races. The experimental plots were prepared by digging pits about one week before sowing. Pits were spaced $2.0 \mathrm{~m}$ both between rows and within rows. Each pit received fertilizers in the following rates: Urea-10.0 g, TSP (Triple Super Phosphate) - 30.0 g, MP (Muriate of Potash) -20.0 g. After application, fertilizers were well mixed with the soil of the pits. The design of the experiment was Randomized Complete Block (RCB) with three replications. The sowing of seeds was done on 14 August 2009. In the experiment, three to four seeds were sown per pit. Seeds germinated in 5-6 days after sowing. When about a month's old, additional seedlings were thinned out keeping one healthy plant in each pit. The young growing plant was supported by a single bamboo stake in each pit. Weeding was done after 25 and 50 days after sowing. No irrigation was applied in the experiment. The experiment was protected from herbivorous animals (e.g. cows, sheep, goats, etc.) and from unauthorized plucking of pods by ensuring careful and continuous watch. Fencing was made around the experimental plots for the purpose. The pods were also protected from aphid attack by applying Diazinon 25 EC@3 ml/1L of water. Harvesting of green edible pods was started in the 2nd week of January, 2010 and continued up to middle of April 2010. The beginning and ending of pod harvest varied depending on the genotypes. Harvesting of mature pods for further data recording was also done during April 2010. Data were recorded from all experimental plants on days to first flowering, days to $50 \%$ flowering, days to first pod setting, no. of pods per plant, wt. of 20 pods. $(\mathrm{g})$, pod yield per plant $(\mathrm{g})$, pod length $(\mathrm{cm})$, number of seeds per pod, number of seeds per plant, 100-seed weight $(\mathrm{g})$, seed yield per plant $(\mathrm{g})$. Divergence analysis was performed by estimating Mahalanobis $\mathrm{D}^{2}$ statistic and the genotypes were grouped into seven cluster. Intra and inter cluster distances, cluster mean and percent distribution of individual character towards divergence were estimated. 
Phenotypic (vp) and genotypic (vg) variances was used to compute the components of variation

\section{Estimation of components of Variation and genetic Parameters}

Components of Variation and genetic Parameters were calculated using the following formula (Singh and Chaudhary, 1985)

\section{a. Components of variation}

Genotypic variance $(\mathrm{Vg})=\frac{\text { Genotypic MS - Error MS }}{\mathrm{r}}$

Phenotypic variance $(\mathrm{Vp})=\mathrm{Vg}+$ Error MS

Phenotypic coefficient of variation $(\mathrm{PCV})=\frac{\sqrt{\mathrm{Vp}}}{\text { Mean }} \times 100$

Genotypic coefficient of variation $(\mathrm{GCV})=\frac{\sqrt{\mathrm{Vg}}}{\text { Mean }} \times 100$

\section{b. Genetic parameters}

$$
\begin{aligned}
& \text { Heritability (broad sense) }: \mathrm{h}_{\mathrm{b}}{ }^{2}(\%)=\frac{\mathrm{Vg}}{\mathrm{Vp}} \times 100 \\
& \text { Genetic Advance, GA }=\frac{\mathrm{k} \cdot \mathrm{Vg} \cdot \sqrt{\mathrm{Vp}}}{\mathrm{Vp}} \\
& \text { Genetic Advance, GA }(\%):=\frac{\mathrm{k} \times \mathrm{Vg}}{\sqrt{\mathrm{Vp}} \times \text { mean }} \times 100
\end{aligned}
$$

Where, $\mathrm{k}=2.06$ (selection intensity at $5 \%$ level)

\section{Results and Discussion}

Genetic parameters, such as the genotypic variance $\left(\sigma_{\mathrm{g}}^{2}\right)$, phenotypic variance $\left(\begin{array}{c}\sigma^{2} \\ \mathrm{p}\end{array}\right)$, genotypic coefficient of variation $(\mathrm{GCV})$, phenotypic coefficient of variation $(\mathrm{PCV})$, heritability $\left(\mathrm{h}_{\mathrm{b}}^{2}\right)$, expected genetic advance $(\mathrm{GA})$, and expected genetic advance in percentage of mean $(\mathrm{GA} \%)$ were estimated for all the characters under study (Table 1). The heritability was categorized as suggested by Robinson et al. (1949), while genetic advance by Johnson et al. (1955). All the characters showed marked differences between GCV and PCV estimates indicating that substantial variation for these characters was contributed by environmental components. Seed yield per plant had the highest GCV (66.39\%). 
Most of the characters displayed high heritability in the study. These high heritabilities might be attributed to genetic diversity and variation. Days to first flowering (DF) had high heritability (97.99\%) with limited GCV (16.04\%) which is consistent with similar result observed by Rahman (1989). Days to first flowering also showing moderate GA in percentage of mean $(32.71 \%)$ and days to first pod setting showed high heritability with low GCV and moderate GA.

Table 1. Estimates of genetic parameters for yield and yield contributing characters in 66 genotypes of lablab bean.

\begin{tabular}{|c|c|c|c|c|c|c|c|}
\hline Characters & $\begin{array}{c}\text { Genotypic } \\
\text { variance }\end{array}$ & $\begin{array}{l}\text { Phenotypic } \\
\text { variance }\end{array}$ & $\begin{array}{c}\text { Genotypic } \\
\text { coefficient of } \\
\text { variation }(\%)\end{array}$ & $\begin{array}{c}\text { Phenotypc } \\
\text { coefficient } \\
\text { of variation } \\
(\%)\end{array}$ & $\begin{array}{c}\text { Heritability } \\
\left(\mathrm{h}_{\mathrm{b})}^{2}\right.\end{array}$ & GA & GA\% \\
\hline $\begin{array}{l}\text { Days to } 1^{\text {st }} \\
\text { flowering }\end{array}$ & 229.65 & 234.35 & 16.04 & 16.20 & 97.99 & 30.90 & 32.71 \\
\hline $\begin{array}{l}\text { Days to } \\
50 \% \\
\text { flowering }\end{array}$ & 183.23 & 189.38 & 13.06 & 13.28 & 96.75 & 27.43 & 26.46 \\
\hline $\begin{array}{l}\text { Days to } 1^{\text {st }} \\
\text { pod setting }\end{array}$ & 171.07 & 175.88 & 11.84 & 12.00 & 97.27 & 26.57 & 24.05 \\
\hline $\begin{array}{l}\text { No. of } \\
\text { pods per } \\
\text { plant }\end{array}$ & 2609.44 & 2611.54 & 64.58 & 64.60 & 99.92 & 105.19 & 132.98 \\
\hline $\begin{array}{l}\text { Wt of } 20 \\
\text { pod }(\mathrm{g})\end{array}$ & 2808.13 & 2863.19 & 25.79 & 26.04 & 98.08 & 108.11 & 52.62 \\
\hline $\begin{array}{l}\text { Pod yield } \\
\text { per plant }\end{array}$ & 257310.37 & 257656.33 & 63.18 & 63.22 & 99.87 & 1044.25 & 130.07 \\
\hline Pod length & 5.85 & 7.63 & 23.36 & 26.68 & 76.64 & 4.36 & 42.13 \\
\hline $\begin{array}{l}\text { No. of } \\
\text { seeds per } \\
\text { pod }\end{array}$ & 0.36 & 1.03 & 13.88 & 23.33 & 35.40 & 0.74 & 17.01 \\
\hline $\begin{array}{l}\text { No. of } \\
\text { seeds per } \\
\text { plant }\end{array}$ & 46225.56 & 52412.7 & 62.98 & 67.06 & 88.20 & 415.94 & 121.3 \\
\hline $\begin{array}{l}100 \text {-seed } \\
\mathrm{wt}\end{array}$ & 111.07 & 113.49 & 15.33 & 15.49 & 97.87 & 21.48 & 31.23 \\
\hline $\begin{array}{l}\text { Seed yield } \\
\text { per plant }\end{array}$ & 23591.27 & 26506.4 & 66.39 & 70.37 & 89.00 & 298.50 & 129.01 \\
\hline
\end{tabular}

Number of seeds per pod had low $\mathrm{h}_{\mathrm{b}}^{2}(35.40 \%)$ with low GCV $(13.88 \%)$ and GA (17.01\%). Rahman et al. (1988) reported low heritability coupled with low genetic gain for number of seeds per pod. The GCV alone is not enough in 
determining the extent of variation, which is heritable. Johnson et al. (1955) suggested that heritability estimates coupled with genetic advance were more useful in predicting the effect to select the best individual. High heritability along with high genetic advance in percent of mean were observed in no. of pods per plant, pod yield per plant, no. of seeds per plant, and seed yield per plant. Such result suggests that improvement of these traits would be effective through phenotypic selection to exploit any additive effect. The values of genotypic and phenotypic coefficients of variation for seed yield per plant were high $66.39 \%$ and $70.37 \%$, respectively and the difference between them was low suggesting limited influence of the environment for the expression of this character. Days to first flowering ranged from 59.33 to 119.33 and for days to $50 \%$ flowering it ranged form 64.33 to 131.0 days among 66 genotypes (Table 2). KBS-7 was the earliest genotypes for both days to first flowering and days to $50 \%$ flowering. DS-118 took the longest period for first flowering and 50\% flowering. Days to first pod setting ranged from 71.00 to 141.67 . DS-118 took longest period for days to first pod setting and the selection of line from a cross took the shortest period for first pod setting (Table 2). The results showed that DS-112 gave the highest number of pods per plant, while DS-27 had the lowest number of pods/plant.DS-99 gave the longest pod and DS-112 the shortest. While 20-pod weight was highest in DS-99 and lowest in DS-118.Pod yield per plant was higher in genotype DS-151 and relatively lower in DS-36.Genotypes DS-19 and DS-99 produced the highest no. of seeds per pod and DS-113 gave the lowest seeds per pod. In case of 100-seed weight, DSN-16 gave the highest seed weight and DS-143 gave the lowest. In case of no. of seeds per plant, the highest value was obtained in genotype DS-151 and the lowest value in DS-27. For seed yield per plant, DS-151 gave the highest yield and DSN-27 the lowest.

Table 2: Maximum and minimum values of representing different characters of mean performance across 66 genotypes of lablab bean.

\begin{tabular}{l|c|c|c|c|c|c|c|c|c|c|c}
\hline $\begin{array}{c}\text { Parame- } \\
\text { ters }\end{array}$ & $\begin{array}{c}\text { Days to } \\
1^{\text {st }} \\
\text { flowering }\end{array}$ & $\begin{array}{c}\text { Days to } \\
50 \% \\
\text { flowering }\end{array}$ & $\begin{array}{c}\text { Days } \\
\text { to } 1^{\text {st }} \\
\text { pod } \\
\text { setting }\end{array}$ & $\begin{array}{c}\text { No. of } \\
\text { pods/ } \\
\text { plant }\end{array}$ & $\begin{array}{c}\text { Wt. of } \\
20 \text { pod } \\
\text { (g) }\end{array}$ & $\begin{array}{c}\text { Pod } \\
\text { yield/ } / \\
\text { plant }\end{array}$ & $\begin{array}{c}\text { Pod } \\
\text { length } \\
\text { (cm) }\end{array}$ & $\begin{array}{c}\text { No. of } \\
\text { seeds/ } \\
\text { pod }\end{array}$ & $\begin{array}{c}\text { No. of } \\
\text { seeds/ } / \\
\text { plant }\end{array}$ & $\begin{array}{c}100- \\
\text { seed } \\
\text { wt }\end{array}$ & $\begin{array}{c}\text { Seed } \\
\text { yield } \\
\text { per } \\
\text { plant }\end{array}$ \\
\hline $\begin{array}{l}\text { Maximum } \\
\text { value }\end{array}$ & 119.33 & 131.00 & 141.67 & 254.00 & 377.67 & 2049.35 & 21.33 & 6.00 & 1035.67 & 83.33 & 840.25 \\
$\begin{array}{c}\text { Minimum } \\
\text { value }\end{array}$ & 59.33 & 64.33 & 71.00 & 9.00 & 110.67 & 89.92 & 5.00 & 2.67 & 45.00 & 39.67 & 35.37 \\
\hline LSD (.01) & 4.627 & 5.293 & 4.681 & 3.092 & 15.84 & 39.74 & 2.850 & 1.741 & 167.09 & 3.320 & 115.02 \\
CV (\%) & 2.29 & 2.39 & 1.98 & 1.83 & 3.61 & 2.32 & 12.90 & 12.75 & 13.04 & 2.26 & 14.34 \\
\hline
\end{tabular}

Genetic divergence among the 66 genotypes of lablab bean was studied by estimating the Mahalanobis $\mathrm{D}^{2}$ statistic. The genotypes were grouped into seven clusters (Table 3). 
Table 3. Distribution of 66 genotypes in different clusters based on various yield and yield contributing characters.

\begin{tabular}{|c|c|c|c|}
\hline Cluster & $\begin{array}{c}\text { No. of } \\
\text { genotypes }\end{array}$ & Percent & Name of genotypes \\
\hline I & 11 & 16.67 & $\begin{array}{l}\text { DSN-24, DS-16, DSN-27, DS-161/C, KBS-1× DS- } \\
\left.\text { 167, DS-113, DS-154× KBS-1, KBS-1(S }{ }_{2}\right), \text { DS- } \\
112 \times \text { DS-164, KBS-7, DS-27 }\end{array}$ \\
\hline II & 13 & 19.70 & $\begin{array}{l}\text { DS-57, IPSA-1, DS-18, DS-19, pigeon black, DS-23, } \\
\text { DS-69/A, DSN-25, DSN-2×DS-167, DS-36, KBS- } \\
\text { 5, DS-106 × DSN-2, DS-106 }\end{array}$ \\
\hline III & 12 & 18.18 & $\begin{array}{l}\text { DSN-52 } \times \text { DS-106, DS-164, DS-35, DSN-13, DS- } \\
\text { 17, DS-168, DS-52, } \\
\text { DSN-26, DS-6, DSN-16, DS-45/B, DS-35/A }\end{array}$ \\
\hline IV & 5 & 7.58 & DSN-4, KBS-2, KBS-1, DSN-8, DS-9(T) \\
\hline $\mathrm{V}$ & 15 & 22.73 & $\begin{array}{l}\text { DSN-12, DS-143, KBS-1(S } 4 \text {, DS-45/A, DS-95, DS- } \\
\text { 118, DS-11, pigeon red, DSN-2, DSN-22, DS-173, } \\
\text { DS-85, DS-10/B, DSN-17, DS-30 }\end{array}$ \\
\hline V1 & 6 & 9.09 & DSN-21, DSN-14, DS-99, DSN-7, DSN-23, DSN-20 \\
\hline VI1 & 4 & 6.05 & DS-151, DSN-6, DS-112, DSN-5 \\
\hline
\end{tabular}

The 66 inbred lines of lablab bean studied were grouped into seven number of clusters. The cluster $\mathrm{V}$ included 15 genotypes, which was the highest, followed by cluster II, which contained 13 genotypes. Cluster III, I, VI, IV contained 12, 11, 6 and 5 genotypes, respectively. The cluster VII included 4 genotypes, which was the smallest among the 7 clusters. Based on percentage the distribution of genotypes into different clusters, cluster V included $22.73 \%$ and cluster II contained $19.70 \%$. The cluster VII had $6.05 \%$ of genotypes, being the smallest cluster. The $\mathrm{D}^{2}$ values between and within the different clusters are shown in Table 4. Cluster I showed the highest inter cluster distance with cluster VII (19302.6), followed by cluster II with VII (18229.9) and cluster VI with VII (16498.66) (Table 4). The minimum inter cluster distance recorded was between cluster II and V (1143.532). The maximum inter cluster distance exhibited between different clusters indicated that genotypes grouped in those clusters were highly divergent from each other. Choosing genotypes from maximum divergent clusters may develop high yielding varieties. The inter cluster distance appeared always higher than the intra cluster distances. Highest intra cluster distance (8502.795) observed in cluster VII revealed maximum diversity among themselves, while the minimum (625.372) indicates closeness of the genotypes belonging to this cluster. 
Table 4. Average inter and intra cluster distances $\left(D^{2)}\right.$ among 66 genotypes of lablab bean.

\begin{tabular}{c|c|c|c|c|c|c|c}
\hline Cluster & I & II & III & IV & V & VI & VII \\
\hline I & $\underline{\mathbf{1 2 9 3 . 3 0 1}}$ & 1227.671 & 3655.151 & 7944.359 & 2059.094 & 5652.132 & 19302.6 \\
\hline II & & $\underline{\mathbf{6 2 5 . 3 7 2}}$ & 3081.2 & 7485.297 & 1143.532 & 6010.683 & 18229.9 \\
\hline III & & & $\underline{\mathbf{1 1 5 5 . 8 1 4}}$ & 2904.353 & 2170.457 & 4140.4 & 9271.425 \\
\hline IV & & & & $\underline{\mathbf{3 7 7 2 . 3 2 3}}$ & 5554.36 & 6515.615 & 7664.0211 \\
\hline V & & & & & $\underline{\mathbf{8 3 5 . 3 2 4 3}}$ & 4531.419 & 15195.89 \\
\hline VI & & & & & & $\underline{\mathbf{1 5 4 7 . 3 2 1}}$ & 16498.66 \\
\hline VII & & & & & & & $\underline{\mathbf{5 5 0 2 . 7 9 5}}$ \\
\hline
\end{tabular}

Note: The underline bold figures are intra-cluster distance.

The cluster mean of the genotypes were estimated and are presented character wise in Table 5. Among the different clusters, the genotypes of the cluster I was earliest for days to $1^{\text {st }}$ flowering. The genotypes in the cluster V, VI and VII took relatively longer time for days to flowering. The genotypes in the cluster I and IV required comparatively low time for $50 \%$ flowering. Considering, days to $1^{\text {st }}$ pod setting; the genotypes in the cluster V, VI and VII took longer period and cluster I the shortest period. The genotypes of the cluster IV and VII produced the highest no. of pods per plant and the cluster I and II produced the lowest no. of pods per plant. The genotypes in the cluster VI and I had higher weight of 20-pod.The cluster VII had the lowest value of 20-pod weight (g).The genotypes of the cluster VI and VII produced higher pod yield per plant; on the other hand, the genotypes of the cluster I and II produced the lower pod yield per plant. The pod length was higher in cluster IV and VI, but lowest in cluster VII. No. of seeds per pod was observed to be higher in cluster IV and lower in cluster V. Like wise no. of seeds per plant was found to be higher in cluster IV and VII, and lower in cluster I and II. The genotypes of the cluster I had the highest value of 100-seed weight, and the cluster IV exhibited the lowest value. Seed yield per plant was found to be highest in cluster VII and lowest in cluster II. Among the different clusters, the cluster VI and VII had high value for most of characters such as 20- pod weight, pod yield per plant, pod length, no. of pods per plant, no. of seeds per plant and seed yield per plant. The genotypes belonging to cluster $\mathrm{V}$ had the longest time for days to flowering and pod setting. On the other hand the genotypes of the cluster I possessed relatively early flowering and early pod setting. Further the cluster VI and VII displayed wide divergence with the genotypes of cluster I. 
Table 5. The Cluster mean values for various yield and yield contributing characters in lablab bean.

\begin{tabular}{l|c|c|c|c|c|c|c}
\hline \multicolumn{1}{c}{ Characters } & I & II & III & IV & V & VI & VII \\
\hline $\begin{array}{l}\text { Days to 1 } \\
\text { flowering }\end{array}$ & 72.27 & 91.59 & 93.47 & 84.80 & 110.11 & 105.89 & 104.50 \\
$\begin{array}{l}\text { Days to 50\% flowering } \\
\text { Days to 1 }\end{array}$ & 83.39 & 101.38 & 103.44 & 95.13 & 118.09 & 111.44 & 112.25 \\
pod setting & 94.82 & 106.10 & 108.33 & 105.40 & 125.38 & 115.28 & 118.00 \\
No. of pods/plant & 42.09 & 37.21 & 102.97 & 142.53 & 58.87 & 112.06 & 192.58 \\
wt. of 20 pod (g) & 229.21 & 185.85 & 187.50 & 185.26 & 202.07 & 295.89 & 160.17 \\
Pod yield/plant (g) & 508.21 & 349.35 & 948.67 & 1316.46 & 606.37 & 1607.72 & 1537.19 \\
Pod length (cm) & 10.85 & 10.77 & 10.61 & 11.27 & 9.18 & 11.95 & 7.75 \\
No. of seeds/pod & 4.06 & 4.95 & 4.17 & 5.07 & 3.98 & 4.44 & 4.08 \\
No. of seeds/plant & 175.00 & 187.85 & 425.11 & 710.73 & 237.42 & 474.67 & 775.34 \\
100-seed wt (g) & 78.99 & 68.19 & 70.99 & 60.10 & 62.56 & 63.84 & 77.33 \\
Seed yield/plant (g) & 137.28 & 124.24 & 301.81 & 426.64 & 144.25 & 304.45 & 599.95 \\
\hline
\end{tabular}

Contribution of the individual characters towards divergence is presented in Table 6. This table shows that no. of pods per plant contributed maximum to the genetic divergence followed by pod yield per plant and 100-seed weight. This means that they were the major characters which influenced the estimation of the $\mathrm{D}^{2}$ values. The rest amount of contribution was noticed through days to $1^{\text {st }}$ flowering followed by days to $1^{\text {st }}$ pod setting, no. of seeds per pod, 20-pod weight, days to $50 \%$ flowering, pod length, seed yield per plant and no. of seeds per plant. Crossing involving genotypes belonging to wide or medium divergent clusters are expected to produce maximum heterosis and variability in genetic architecture. Therefore, genotype having better perse performance under clusters I, II, V, VI and VII could be selected for variety improvement program in lablab bean.

Table 6. Percent of contribution of individual characters towards divergence.

\begin{tabular}{l|c}
\hline Characters & Contribution (\%) towards divergence \\
\hline Days to $1^{\text {st }}$ flowering & $6.294 \%$ \\
Days to $50 \%$ flowering & $1.492 \%$ \\
Days to $1^{\text {st }}$ pod setting & $3.683 \%$ \\
No. of pods/plant & $34.033 \%$ \\
20 pod wt. & $1.725 \%$ \\
Pod yield/plant & $30.629 \%$ \\
Pod length & $1.072 \%$ \\
No. of seeds/pod & $2.844 \%$ \\
No. of seeds/plant & $0.093 \%$ \\
100 -seed wt & $17.902 \%$ \\
Seed yield/plant & 0.233 \\
\hline
\end{tabular}




\section{References}

Bailey, L.H. 1942. The standard cyclopedia of American Horticulture Vol. 1 (A-E) Macmillan Co. New York, p. 1065.

Bullivant, S. H. 1963. Farm crops. Book one. Rural Education Longmans Green and Co. London, $\mathrm{p} 10$.

CFLIP (Coordinated Food Legume Improvement Project).1988. Annual Report for 198788, Report No. 1: 51-74.

Chakravarty, A. K. 1986. Dolichos bean. Pp. 524-528. In: vegetable crops in India. T.K. Boss and M.G. Som (ed) Naya prokash, Calcutta, India, 775 Pp.

Chowdhury, A.R.; Ali, M. and Quadir, M.A. 1989. Aspects of Pollination and floral biology of lablab bean (Lablab purpureus L. Sweet). J. of the Japanese Society for Horticultural Sci., 58(3): 665-71. Pl. Br. Abstr., 60 (12): 1567.

Johnson, H.W.; Robinson, H.F. and Comstock, R.E.1955. Genotypic and Phenotypic correlation in Soybeans and their implications in selection. Agron. J. 47(10): 473- 483.

Katyal, S. L. and K. L. Chandha, 1988. Vegetable growing in India. $2^{\text {nd }}$ Ed. Oxford and IBH publishing Co., New Delhi-110020, p. 68.

Nath, P. 1976 a. Vegetables for the tropical region. ICAR. New Delhi, p. 40.

Nath, P. 1976 b. Vegetables for the Tropical Region, ICAR, New Delhi, (cited from vegetable crops in India. Ed. Bose. T.K., Som, M.G. 1986). Naya Prokash, Calcutta-6, P. 525.

Newaz, N. 1992. The composition of germinating lablab bean seed and the functional characteristics of its flour. Proc. BAU. Res. Prog. 6: 230-237.

Purseglove, J. W. 1977. Tropical corps. In: Dicotyledons. Longman, London, Pp. 273-276.

Rahman, M. M., F. L. Alam, K. M. Kabir and M. A. Quasem. 1988. Genetic parameters and character association in hyacinth bean (L. purpureus L. Sweet). Bangladesh J. Plant Breed. and Genet. (1\&2): 123-128.

Rahman, M. M. 1989. Study of genetic variation and heterosis in lablab bean. M. Sc. (Ag.) Thesis, Genet. and Plant Breed. Dept., Bangladesh Agric. Univ., Mymensingh

Rashid, M. M. 1976. "Bangladesher Sabji" (Vegetables of Bangladesh). Bangla Academy, Dhaka. Bangladesh, Pp. 313-23.

Robinson, H. F., R. E. Comstock and P. H. Harvey. 1949. Estimation heritability and degree of dominance in corn. Agron. J. 41: 353-359.

Singh, R. K. and B. D. Chaudhary. 1985. Biometrical Methods in Quantitative Genetic Analysis. Kalyani Publishers, New Delhi, India.

Tindall, H. D. 1988. Vegetables in the Tropics. Macmillan Education Ltd., London, P. 268-69.

Uddin, M. R. 1975. A comparative study of the performance of some selected F4 lines, their parent and established varieties of rice (Oryza sativa, L.). An M.Sc. (Ag.) Thesis, Dept. of Genet and Plant Breed., BAU, Mymensingh.

Wood, F. W., 1983. Lablab bean (L. purpureus) for grain and forage production in the irrigation area. Aust. J. Exp. Agric. Animal Husb. 23: 162-171.

Yamaguchi, M. 1983. World vegetables, Principles, production and nutritive values. The AVI Publishing Co., USA, Pp. 278-297. 